ARTIGOS 



\title{
Invisibilidade e hipervisibilidade dos muçulmanos no extremo sul do Brasil: os contornos da vida comunitária e os preceitos islâmicos em ato entre imigrantes de origem palestina
}

\author{
Denise Fagundes Jardim
}

Universidade Federal do Rio Grande do Sul, Rio Grande do Sul, Brasil E-mail: denisejardim@yahoo.com.br 


\section{Resumo}

Desde 1996, a ausência ou a presença controlada de líderes religiosos junto às famílias de imigrantes palestinos no extremo sul do Brasil, indaga-se sobre a "falta de" uma mesquita e a opção por uma sala de oração situada na Sociedade Beneficente Árabe-Palestina numa cidade do extremo sul do Brasil. Acompanhando a comunidade por mais de 10 anos, percebe-se que a sala de oração comportara visitas esporádicas de Cherks, mas até então, os líderes religiosos "de carreira" eram acolhidos tão somente como visitantes e hóspedes da comunidade. Somente no ano 2000 reconheceu-se a presença de um potencial Imam. Esse é um processo revelador de aspectos da vida religiosa e da ingerência da comunidade local na sua experiência cotidiana e de suas relações com não muçulmanos, indicando processos ora de hipervisibilidade ora de invisibilidade da religiosidade muçulmana entre os imigrantes.

Os estudos sobre islamismo vêm sendo organizados na atualidade dando ênfase ao estudo da islamofobia, se contrapondo a noções reduzidas sobre a experiência religiosa, e aos nexos entre as práticas muçulmanas e a presença imigrante em sociedades em que o cristianismo é preponderante. Indago sobre algumas das ciladas metodológicas mais comuns na organização de trabalhos etnográficos sobre as práticas muçulmanas. Como propusera Geertz, tomo a religião como sistema cultural e procuro redirecionar as perguntas que costumeiramente formulamos em campo. Não estaríamos pautados prioritariamente pelo sentido de "revelar" as práticas religiosas nativas?

Palavras-chave: Imigrações palestinas. Islamismo. Mídia. Moralidades.

\section{Abstract}

Since 1996, the absence, or the controlled presence, of religious leaders amongst Palestinian immigrant families in southern Brazil has lead me to inquiry as to the reason for the "absence" of a mosque and the choice of a prayer room located in the Sociedade Beneficente Árabe-Palestina, in a town located in the southern most part of the country. During more than ten years of fieldwork in the community, we have noticed that the prayer room receives occasional visits by Cherks, but until recently, "career" religious leaders were only visitors and guests to the community. It was only in 2000 that the presence of a potential Imam was acknowledged. This process revealed various aspects of the religious life and the affects of the local population upon the daily experience and relations with non-Muslims, pointing out processes of both hipervisibility and invisibility of Muslim religiosity amongst immigrants.

Contemporary research on Islamism has focused on islamfobia, countering reductive notions about religious experience, and attending to the connections between Islamic practices and immigrant presence in predominantly Christian societies.

This essay focus on some issues regarding common methodological dead-ends in ethnographies of Muslim practices. As Geertz suggested, we take religion as a cultural system, seeking to redirect the questions we commonly ask during fieldwork. Have we not been guided, primarily, by the quest to "reveal" native religious practices?

Keywords: Palestinian immigration. Islamism. Media. Moralities 
$\mathrm{N}$ este artigo pretende-se abordar a experiência de muçulmanos no extremo sul do Brasil a partir de constantes incursões de pesquisa com os imigrantes palestinos que vivem na fronteira entre o Uruguai e o Brasil, Chuí1. Trata-se aqui da hiperexposição à mídia, para não descorporificar o que se refere constantemente como o senso comum, e como os interlocutores tentam ajustar sua autoimagem em um jogo de estereótipos. Depois passa-se a refletir sobre a presença/ausência de líderes espirituais em um universo de pesquisa específico.

A proposta desse artigo é estimular uma abertura do campo de visão sobre a experiência muçulmana levando em consideração os jogos de estereótipos e estigmas que tornam os muçulmanos ora invisíveis como fenômeno religioso, ora hipervisíveis como alteridade. Colocase em relevo o fato de que os imigrantes muçulmanos atuam nessa arena buscando, de modo muito limitado por certo, manter algum controle sobre sua autoimagem. Além disso, permite-se entender um ponto de observação e avaliação sobre moralidades, formando parte de um campo discursivo e não somente agindo no sentido de controlar sua autoimagem. Para tanto, é importante retomar as propostas de Cardoso Oliveira (RBCS, n. 24, 2011) ao considerar os encontros e os desencontros produzidos na fusão entre horizontes morais, a fim de não encapsular a experiência dos muçulmanos, em sua pluralidade e situacionalidade, como a experiência de muçulmano, orientalizando os sujeitos e os desenraizando de seus contextos de enunciação.

As noções de sunismo e xiismo são relevantes para compreender não só a história do islamismo, mas sua pluralidade e seus desdobramentos históricos, mas têm sido importantes para entender a expansão do número de mesquitas em diferentes lugares no Brasil². Em geral, as mesquitas dão maior visibilidade à presença muçulmana e refor- 
çam a inclinação por focar a experiência religiosa através da relação dos muçulmanos com líderes espirituais e nas mesquitas; e reforçam também a relação de pesquisa com os Imans.

No que tange à experiência religiosa, como lembra Otávio Velho (1997), o desafio é o "de desconstruir nossos hábitos profissionais". Propõe-se deslocar a atenção para as batalhas de moralidades vividas cotidianamente, inclusive, entre os imigrantes. Aqui pretende-se ser breve e talvez falte tempo para fornecer elementos mais claros sobre este universo de pesquisa.

Examina-se um universo de pesquisa de imigrantes palestinos e de seus filhos nascidos no Brasil ou países do Oriente Médio que ingressam no Brasil no final dos anos de 1950. Eles estão situados no comércio, um dos lugares por excelência do encontro e da negociação. São comerciantes, alguns muito bem-sucedidos com grandes supermercados, outros apenas vendedores ambulantes ou sócios em pequenos estabelecimentos temporários. Relacionam-se diretamente com uma camada média na localidade, embora mantenham lugares de sociabilidade próprios na cidade, e se concentram em determinadas ruas da vida comercial. É impossível vê-los alheios às pessoas com quem, ao fim e ao cabo, estudam juntos no mesmo colégio, compartilham os mesmos lugares de sociabilidade em uma cidade de cerca de 3.000 eleitores $^{3}$. Se não houvesse tanta relação direta e necessária, talvez não se escutasse tantas "queixas" recíprocas e uma potencial proliferação de estigmas e estereótipos.

\section{Notícias do "outro mundo": sobre a (hiper)visibilidade}

Ao longo dos últimos 15 anos, os imigrantes palestinos no Sul do Brasil têm sido interpelados como um "perigo" pela mídia uruguaia. Reiteradas vezes, a imprensa brasileira oscilou entre os considerar ora como "fonte" de informação sobre o ponto de vista árabe a respeito de diversos conflitos transcorridos no Oriente Médio, ora como "foco" de indagações, decodificando através deles os significados do islamismo.

Acumulando experiências e desconfianças com relação à presença e aos procedimentos de jornalistas, estes interlocutores evidenciam os usos de estereótipos que recaem sobre os imigrantes de origem pales- 
tina e muçulmanos. Essa batalha de imagens, identificadas durante o trabalho de campo, tem realçado algumas de suas estratégias para fazer frente a tais imagens pré-fabricadas que reiteram a "diferença" como "um mundo à parte" que persiste entre "nós".

Os interlocutores se reportam ao ano em que Arafat fora reconhecido como legítimo representante do povo palestino pela ONU, em 1988. Realizaram a passeata pelo "dia da terra", mobilizando políticos locais e transformando a localidade num ponto de conexão com a questão palestina ${ }^{4}$. A imagem da comunidade já se encontrava vinculada à denúncia e ao pleito por justiça pela violação de direitos humanos, como a denúncia dos massacres de Sabra e Chatila em 1982 e a participação de jovens na organização do sanaud nos anos de $1980^{5}$.

A percepção inicial da relação entre árabes com a mídia detinhase nos aspectos mais relevantes de seus vínculos locais e extralocais. Assim como o fax e o telefone (ainda não se utilizava em larga escala a internet em 1995), sintonizar a TV Dubai, pelas antenas parabólicas, dava pistas sobre essas maneiras de reforçar tanto a sociabilidade de rua entre árabes, nas conversas em calçadas, quanto a capacidade de monitorar a distância o contexto político que era vivenciado por seus parentes. Através da TV Dubai, eles podiam ver juntos a transmissão das orações nas lojas. Muitos dos planos de visitas aos parentes eram protelados em função da avaliação da situação política e bélica, trazida pelos noticiários da Rede Dubai ${ }^{6}$.

Colecionadas as maneiras espetaculares com que as mídias abordam sua presença na fronteira, seja por estarem na fronteira entre Uruguai e Brasil, seja por serem árabes, um estrangeiro potencializado, observa-se sempre um recém-chegado. Os interlocutores já acumularam inúmeras experiências diretas com um difícil diálogo com as distintas mídias: televisiva, rádio, escrita, e com aquilo que aprenderam a configurar como "o jornalista". Suas experiências malsucedidas com jornalistas eram constantes; eles reincidiam em adotar um orientalismo midiático, constantemente a "decifrar" algo diferente e, ao mesmo tempo, a exotizá-los como pessoas "fora de lugar".

Alguns episódios ilustram essa perspectiva orientalista, aqui brevemente citados: 


\section{Episódio 1}

Em julho de 1994 houve a explosão criminosa da AMIA (Associação Mutual Israelita Argentina) em Buenos Aires, resultando no fechamento das fronteiras argentinas e a prisão dos suspeitos terroristas em Ciudad del Este. Depois da explosão da AMIA, a atenção para as fronteiras realçou a presença árabe.

Nesse contexto, subestimar ou superestimar sua presença na fronteira não era uma atitude inocente, e, sim, o resultado de uma negociação entre jornalistas e imigrantes travada contextualmente. Ora amenizando a força da comunidade árabe, como presença internacional, ora realçando sua força política na localidade, como sujeitos relevantes na economia local, o número se expandia ou se reduzia.

\section{Episódio 2}

Em 3 de fevereiro de 1999, o El País uruguaio descreve "El Chuí, una tierra de enigmas", trata da colônia árabe e interroga: quantos "Chuís" existem na localidade, para além do Chuí uruguaio e do brasileiro? Centra-se na prisão do egípcio Said Ali Mohamed Mukhlins na cidade e na presença da "colônia", ressaltando o fato de que esposa e filho do egípcio estavam hospedados na casa do prefeito da cidade brasileira, Mohamed Jomaa. No dia 5 de fevereiro, dois dias depois, a Folha de São Paulo (BR) destacava a prisão do egípcio: "Egito quer prisão de suposto terrorista". O artigo tem como fontes os jornais uruguaios e realça as ligações entre o egípcio e as organizações terroristas ligadas ao atentado em Luxor, sul do Líbano, em 1997, que matou 58 turistas. Em detalhes da reportagem estão os depoimentos de comerciantes locais, do próprio prefeito e a localização geográfica do Chuí.

Esses fatos têm desdobramentos. Outras reportagens se referem ou justificam a presença da CIA em Foz do Iguaçu e, de outra parte, veiculam os protestos da comunidade árabe quanto a tal presença e os danos que ela significa para sua vida transcorrer com normalidade, revelando também reclamações da comunidade árabe fronteiriça de Foz do Iguaçu. 


\section{Episódio 3}

Trata-se da operação zero-quilo, que visa bloquear o contrabando de alimentos por parte do prefeito Mohamed Jomaa e que gerou um conflito diplomático entre Brasil e Uruguai no ano 2000.

\section{Episódio 4}

Os imigrantes foram interpelados sobre as conexões internacionais relativas ao ataque de 11 de setembro, em 2001. Diversos jornalistas foram enviados para interpelar os imigrantes no Chuí. Alguns são lembrados pelos próprios imigrantes pelos danos causados à autoimagem da localidade, em especial, o jornalista Carlos Wagner, da RBS.

\section{Episódio 5}

Em 2006, durante a Guerra no Líbano (ou a invasão do exército israelense em território libanês), a imprensa brasileira centrou-se no resgate aos brasileiros, e a evidência da predominância de sobrenomes árabes entre eles se sobressaía. De igual maneira interpelou os imigrantes palestinos na localidade do Chuí como uma chave de leitura, realçando a possibilidade de, através deles, divulgar a versão "do outro lado" da guerra a partir de entrevistas com esse "outro" que habitaria entre nós. Seria um contraponto aos inúmeros enviados e correspondentes da imprensa não árabe mundial.

Esses episódios, aqui brevemente relatados, permitem evocar cinco momentos em que as mídias televisivas fizeram uso e reiteraram imagens orientalizadas dos imigrantes. Cabe indagar sobre o modo como nós pesquisadores abordamos (ou não) a presença da mídia entre nossos interlocutores como parte de uma arena de produção de estereótipos. O risco maior como etnógrafos é o de navegar dentro dessa batalha de imagens e reduzir o nosso próprio campo de atuação a uma contínua e repetitiva refutação e desconstrução de imagens estereotipadas sem evidenciar um jogo tenso de disputas e reelaboração de estereótipos por parte desses imigrantes. 


\section{Os estereótipos, o controle da autoimagem e suas distorções}

Pode-se voltar ao 11 de setembro de 2001, quando ocorre o ataque às torres gêmeas. Os jornalistas que se dirigiram aos imigrantes árabes no Chuí já adotavam um outro patamar de interlocução. Valorizavam os interlocutores como parte da busca de outras fontes de informação, assim como foram ensinados anteriormente por seus interlocutores nos fatos precedentes. Assim, um entrevistado imigrante passa a ser relatado por jornalistas como um decodificador do mundo árabe, nos textos das reportagens. Esse recurso para o diálogo se torna o modo prioritário dos jornalistas que, mais uma vez, correram ao Chuí e a outras cidades de fronteira sul para buscar neste contingente de imigrantes as repercussões do ataque ao World Trade Center (WTC) e, uma vez mais, dar contornos e visibilidade a uma "comunidade árabe". Mas, nessa oportunidade, os imigrantes diziam que, na realidade, os jornalistas "vieram saber se o fato havia sido comemorado [o 11 de setembro] com fogos de artifício ou não" pela comunidade local (e árabe).

Havia um jogo de expectativas e de suspeitas com a interpelação da mídia, em que os imigrantes buscavam interferir na imagem produzida pelos meios de comunicação como pessoas autorizadas a discorrer sobre o "mundo árabe". Entendiam que tal imagem recairia também sobre os imigrantes como representativos deste outro mundo. Em outra oportunidade, realça-se (Magalhães; Jardim, 2009) que havia uma especialização por parte dos migrantes para analisar a mídia e também uma experiência direta em manejar a autoimagem perante os jornalistas que farão novas imagens sobre os árabes e os muçulmanos.

Para perceber isso é necessário observar de perto os interlocutores.

\section{Episódio 6}

Eu chegara alguns dias depois do 11 de setembro de 2001 e, como minhas visitas e retornos de pesquisa eram recorrentes, me explicavam como tinham "se acertado" sobre como se portar perante os jornalistas. Segundo eles, só uma pessoa concederia entrevista e todos os demais imigrantes assim indicariam a mesma pessoa como único porta-voz. Referiam a preocupação com a prática dos jornalistas de editar, ou seja, "cortar frases" de um e outro, e 
remontar com novo sentido. Essa era a estratégia encontrada para evitar a edição e cortes das vozes, depoimentos e imagens que poderiam resultar em uma fala "distorcida". Aquilo que é visto como polifonia para os jornalistas, era visto como o risco de não controlar inteiramente o que se escreveria sobre a comunidade local. Sintetizam isso como um "torcer as palavras", termo mais comum empregado para se referirem às experiências pregressas que sofreram com as mídias.

Por telefonemas, eles eram instruídos por seus amigos uruguaios a readequarem suas próximas entrevistas, enfatizarem que viviam no Brasil, dado que as duas cidades têm o mesmo nome no Brasil e Uruguai; e isso era apagado do contexto da entrevista. Nesse jogo de invisibilidade e supervisibilidade ao gosto de quem maneja a informação e seu produto televisivo, apareciam de forma equivocada como uma comunidade árabe no Uruguai.

Depois dos atentados de 11 de setembro, redobraram as precauções sobre o que dizer para a mídia - notadamente controlando as expressões antiamericanas que eram destacadas pela mídia (brasileira no caso) como se fosse algo manifesto unicamente por membros da comunidade árabe ${ }^{7}$.

Onde estou nesse episódio? Junto ao balcão de um dos comerciantes mais antigos da cidade. Em sua loja eu testemunhava os telefonemas e uma espécie de monitoramento sobre a presença e ir e vir dos jornalistas. Não era algo muito difícil, são poucas quadras e muitos telefonemas. Quando uma das jornalistas entra na loja e se apresenta para o comerciante que estou conversando, ele retira um dos volumes da revista Horizontes Antropológicos de sua gaveta (que publiquei) e explica para a jornalista que eu já tinha estudado, tinha feito doutorado, sobre os palestinos e ela poderia consultar as publicações. Evidente que ao dispensar a jornalista ele, de fato, me repassou o encargo de me ocupar dela. Pode ser que ele tenha também, dessa vez, tentado se livrar de dois incômodos ao mesmo tempo.

Não é possível compreender esse episódio, sem considerar uma contínua interpelação a que eles foram expostos desde os anos de 1990. Na localidade e, em especial, na chamada Rua Jenin (Rua Colômbia) ${ }^{8}$, o controle da autoimagem perante os olhos dos outros não era uma situação banal. Lá, os sujeitos interpelados pelas mídias se encontravam no espaço público, reúniam-se em pequenos grupos para trocar 
ideias e conversar, e agiam no sentido de resguardar a autoimagem de grupo, interferindo também no debate sobre a economia (atuando no Conselho de diretores lojistas) e na política partidária local. Conceder uma entrevista a um forasteiro tem suas consequências nas relações locais, na fiabilidade do sujeito perante os demais e, por certo, não é uma atitude banal.

Acredita-se que é necessária uma nova disposição (ou postura metodológica), que exige pensar mais detidamente sobre os modos como os imigrantes se relacionam, manejam a mídia e interferem na produção de estereótipos 9 . Os episódios indicam um acúmulo de experiências diretas dos imigrantes em uma cadeia temporal mais longa.

Aparecem aí os aprendizados acumulados e um uso reflexivo da mídia para tentar conduzir os jogos de estereotipia de uma imagem positiva da comunidade de imigrantes.

\section{Um lugar no mundo: (in)visibilidades estratégicas}

Em uma outra escala, mais próxima à vida local, a batalha de estereótipos também não é um jogo de contrastes óbvios e constantemente escorrega para essencializações. Entrar em contato com os palestinos era também entrar em contato com a "suspeita" de condutas morais incompreensíveis para os "locais", sobre a maneira como imigrantes árabes se comportariam.

Em muitos casos, suspeita-se que a postura de retidão exigida pelo islamismo não era seguida à risca. Os modos como os árabes tratariam suas relações maritais, em especial a acusação de poligamia, a potencial propensão à traição dos maridos, ou a preferência em casar seus filhos somente com as filhas de imigrantes árabes com "árabes". Algumas situações poderiam reforçar os estereótipos, como as grandes celebrações de casamentos, que envolviam centenas de convidados oriundos de distintos lugares do país e de outros países para a festividade. O "casamento arranjado" é tão conhecido dos filhos de imigrantes quanto dos locais. Não causava tanta estranheza, mas reiterava a certeza de que "eles casam entre si". Ou seja, de que com as brasileiras só namoram, pois casam com árabes. 
Essa proliferação de estereótipos e de acusações não constitui um todo coerente, mas um terreno de acusações morais constantes e cambiantes ${ }^{10}$. De certa maneira, se exige também uma "coerência" com a cultura do "outro". Nessa escala mais cotidiana, é possível perceber como os sinais que identificam as fronteiras entre muçulmanos e não muçulmanos aparecem de modo discreto, performáticos e debitando na "diferença" as certezas oriundas de um terreno de acusações morais.

Embora esse seja um aspecto visível, nem sempre há uma unanimidade entre os próprios imigrantes na leitura de seus significados. Alguns identificam os usos públicos de objetos religiosos como, tão somente, uma proximidade maior com a vida familiar na palestina ou em países do oriente médio; outros, com aqueles que seriam mais "tradicionalistas" do que outros imigrantes.

A religiosidade pode corresponder ao momento atual do imigrante, seja como uma retomada de uma atitude mais próxima ao cumprimento dos cinco pilares do islamismo, especialmente a hajj (a peregrinação), ou mesmo por provocar uma explicação sobre um afastamento, visto como momentâneo, decorrente do reconhecimento de que a prática deve ser feita com a dedicação necessária, a qual a pessoa em questão não teria muita oportunidade no momento, por dedicar-se inteiramente ao trabalho. Ou, por revelar itinerários de imersão na religiosidade muito variados, mesmo que associados com outras experiências religiosas disponíveis, como o espiritismo, ou realçando diferenças de imersão ou não entre irmãos de uma mesma família.

Se a religião não é evocada na cena pública perante os não muçulmanos, o nacionalismo palestino ocupa esse lugar: esteve muito mais presente em eventos públicos, nas manifestações políticas, nas celebrações de casamentos, nas formas de comunicar aos locais a distintividade da coletividade palestina, ao trazer os jovens filhos de imigrantes ao convívio da comunidade imigrante através de grupos jovens como o sanaud, bem como exigir reconhecimento público na inter-relação com não árabes.

Mesmo que a religião não ocupasse o primeiro plano nas relações que travavam com não muçulmanos, a religiosidade estava sempre ali como parte de uma prática cotidiana para dar a devida dimensão dos significados dos cinco pilares do islamismo, para apresentar ao 
entrevistador; e são constantes os entrevistadores. De forma didática, eles explicavam que o testemunho de fé, a prece, a zakat (esmola), a peregrinação à Meca (hajj) e o jejum no mês do Ramadã (recuperando o ano VI da Hégira, um retorno a casa) expressam uma religiosidade da observação de condutas, de purificação e de atos de bondade que neutralizam atos ou más inclinações. E, no diálogo sobre a observação de condutas, transpareciam preocupações convergentes sobre "os perigos da rua", e não exatamente sobre a distintividade do muçulmano.

Particularmente, desfrutava-se desse ir e vir dos comerciantes na rua Colômbia. As conversas entre homens beiravam a atitudes didáticas sobre suas vivências como pessoas que se tornaram comerciantes e que ensinavam aos jovens comerciantes um caminho de sucesso. Entretanto, também estavam ali pessoas mais velhas que tinham falido em seus negócios, ou que não tinham perspectiva senão de vender comida árabe de porta em porta para os comerciantes. Comer um kibe ou conversar sobre o islamismo eram fatos que atravessavam as conversas na calçada. Foi assim que fui interpelada por um senhor que, para me explicar o islamismo me trazia panfletos xerocados (que eu já conhecia como de grande circulação no Rio de Janeiro) e fazia uso de exemplos que seriam mais próximos de minha vivência. Comentava sobre a proximidade possível entre os comportamentos e as reflexões de Renato Russo com o que seria o sufismo e o descolamento do sujeito das razões desse mundo. Ao mesmo tempo em que eu indagava sobre a ausência de mesquita, uma de minhas maiores inquietações durante a primeira fase de trabalho de campo. Para isso, havia duas ou três respostas recorrentes: uma, que era desnecessária, pois era uma religião em que a conduta é mais importante do que uma grande obra; a segunda resposta se reportava ao rechaço potencial a uma estrutura e organização que se colocaria sobre uma associação local e que poderia significar imposições; e a terceira, dirigida a mim, falava que a mesquita da mulher era a sua própria casa. Essa última razão, me revelava mais diretamente um debate sobre moralidades e que, de fato, perpassava também todas as razões anteriores.

As diversas pistas relativas à religiosidade se deslocavam para o terreno das condutas e na batalha das moralidades, tão constantes 
nas relações locais (e não exclusivamente com não muçulmanos). A figura do Iman quase sempre era considerada como prescindível e periférica em comparação com a observação de condutas e a vigilância recíproca entre imigrantes. Isso explicaria a ausência (histórica) de uma mesquita na localidade, e a ausência de líderes espirituais que estudaram o Corão, como os Imanes.

Nesse contexto, reforçava-se a percepção de que para a vida em comunidade, o exemplo de Maomé, a sunnah, é mais valioso do que um sermão do Iman, que precede as orações, e que falaria sobre as mazelas da vida comunitária. Nesse caso, a religião e a religiosidade não eram parte de um processo de comunização em seu sentido pragmático, visando uma boa inserção junto a locais, mas sim repercutiam em formas de comunização no sentido de delinear um campo de interlocutores, uma comunidade moral, com suas tensões e formas de exercer uma vigilância sobre condutas e limites.

\section{As olhos dos outros: estereótipos, condutas e destinos}

Ocorre que nossa percepção sobre o lugar da religiosidade muçulmana na experiência imigrante decorre de duas assertivas básicas do etnógrafo iniciante. Uma, de que a religião deveria estar em primeiro plano, propiciando a vida comunitária do imigrante, como uma religião de grupo minoritário, reforçando aquilo que é fragilizado por essa outra temporalidade da sociedade de acolhida, uma ferramenta de inserção. A outra assertiva é que a religiosidade faz parte de um ato comunicativo relevante na relação com não muçulmanos, evidenciando aspectos emblemáticos da identidade desses imigrantes e de sua alteridade e a relação com não imigrantes, não muçulmanos.

Os imigrantes pareciam resistir a essas assertivas, evitando apresentar-se na cena pública como muçulmanos, preferindo colocar em primeiro plano os aspectos positivos, associados ao direito humanitário internacional e ao reconhecimento do Estado Palestino pela ONU, nos anos de 1980. Já na época, isso os retirava, junto com Arafat, do estigma de terroristas.

No Chuí, a sala de oração dentro do clube árabe, o recente cemitério islâmico (dos anos de 1990) localizado junto ao clube árabe 
e a inexistência de uma mesquita, me levavam a indagar sobre o lugar da religiosidade na vida comunitária. Boa parte de suas práticas religiosas exercitam a purificação corporal. É com a observação da conduta individual que sua religiosidade se torna mais evidente para seus familiares e vizinhos. O jejum do Ramadã, mesmo com o apoio familiar, não é um ritual exercido por famílias inteiras, mas coloca em relevo o "bom exemplo" de um pai ou mãe para o filho(a) que optou por realizar de forma plena o jejum; e assim debatem seus significados pela experiência direta.

No caso destes interlocutores, chamava a atenção sua desconfiança com a eficiência de ter um Cherk residindo entre eles. "Desnecessário", explicam-me, pois o muçulmano deve seguir cinco preceitos (pilares) fundamentais durante a vida, não necessita de um líder religioso. Ao mesmo tempo, nas sextas-feiras, alguns comerciantes seguiam para a oração na sala de oração do clube. O lugar não é uma unanimidade; deveria ser um lugar de extrema pureza, mas por comportar mesas para jogar cartas no andar de baixo, no grande salão, não é visto pelas mulheres como um local adequado. O interessante é que, perguntados por que as mulheres não vão à sala de oração, respondem que a casa é a mesquita das mulheres, referendando alguns estereótipos fáceis sobre o lugar da mulher no islã.

Essa fluidez da religiosidade poderia ser debitada tanto na declaração de uma resistência em adotar uma mesquita, cujo gestionamento passaria por líderes espirituais oriundos da Arábia Saudita, mas também nas dificuldades em manter práticas e rituais religiosos em um contexto não muçulmano. Segundo Joan Lacomba Vázquez (2000), alguns preceitos muçulmanos, como seguir o jejum do mês do Ramadã, consumir carne com práticas sanitárias no abate (halal) ou mesmo seguir rituais que envolvem datas que exigem a comensalidade nas relações de vizinhança, seriam fragilizadas exatamente por estarem em um contexto plurirreligioso que invisibiliza a capacidade de alguns rituais de alcançarem um grande impacto e instaurarem uma outra temporalidade, tornando sua prática fundamental para disciplinar as condutas, algo mais frágil.

Não é exatamente o caso do Chuí nos anos de 1990. O predomínio de falantes do idioma árabe nunca pudera tornar invisível a existência 
dos muçulmanos na localidade, nem tornaram as referências à origem e práticas muçulmanas algo sem importância. Mas para enxergar os muçulmanos é preciso um olhar treinado sobre pequenos atos, notar as constantes ausências da loja no momento da oração, observar quais os objetos expostos em suas casas. Os objetos trazidos da hajj (peregrinação) ora adquiriam um sentido religioso ora um sentido turístico. Essa ambivalência era constante e dependia do conhecimento e o interesse do interlocutor.

Nesse contexto, a ingerência da religião, através de lideranças religiosas - com os quais os antropólogos estão acostumados a dialogar - não acompanhava os sentidos e práticas relacionadas à religiosidade. Não se quer dizer que as práticas muçulmanas se desenvolvam no âmbito privado; sempre houve no clube árabe uma sala de oração e, atualmente, o clube teve instalado finalmente um autofalante para amplificar a Adham (o chamado para a oração).

No Chuí, "os olhos dos outros", vizinhos e familiares, estiveram sempre presentes. Não seria possível saber mais o que é a vigilância alheia e o que é observação e aprimoramento de sua conduta, exigida pelo islamismo. Há uma enorme vigilância sobre as condutas entre os pares em uma cidade de pequenas dimensões, permeados por inúmeros conflitos reais e potenciais, em que os comerciantes observam quem prospera rápido demais ou leva outros à falência, ponderando sobre a capacidade e empenho no mundo do trabalho, sobre o comprometimento do comerciante ou das esposas com os negócios, ou da não compreensão das conversas travadas em árabe e que instigam pais e mães a ensinar seus filhos a falar e "se defender" da opinião pública.

É na observação das "condutas" e no campo das moralidades que se pode ver os preceitos islâmicos em atos, não exatamente como uma "outra cultura", um "outro mundo", mas como uma prática religiosa que aciona um comentário sobre as condutas corretas que devem ser observadas na vizinhança. Como sugere Geertz (1989, p. 143), a religiosidade tem um sentido metafísico, ético e é uma experiência emocional; poderia se dizer: sensível aos olhos do outro, mesmo que aparentemente e corporalmente possa se apresentar como um aprimoramento de uma conduta individual. 


\section{Comentários finais}

Com essas reflexões em pontuais episódios vivenciados durante as observações realizadas em campo, relativiza-se a centralidade que se confere aos líderes religiosos e às mesquitas, consoante com as preocupações que já se tece no campo de estudos etnográficos sobre religiosidades afro-brasileiras ou do catolicismo. Imaginem a frustração inicial quando a sala de orações encontrava-se vazia e o clube era mencionado como um lugar "abandonado"! A religiosidade parecia, sim, estrategicamente invisibilizada pelos imigrantes, mas presente como referência oferecida aos olhos de não migrantes. De um lado há que se considerar as desastrosas experiências de hipervisibilidade midiática que eles tiveram no decorrer dessas duas últimas décadas. Assim, tanto a religiosidade como a sala de orações tinham menos visibilidade do que a evocação do dia da terra e a evocação do reconhecimento da OLP, tema que acaba predominando, em minha tese, em detrimento das expressões de religiosidade.

Além disso, a comunidade não recebe por muito tempo, cerca de 10 anos, a presença continuada de Cherks na localidade. Paradoxalmente, isso é pensado como uma redução de conflitualidade na comunidade, pois, potencialmente, um líder espiritual de fora ou um líder religioso da Arábia Saudita poderiam tocar em temas muito sensíveis aos imigrantes.

No ano 2000, um filho de imigrante retornou à cidade, casado, depois de um período de formação em engenharia na palestina e assumiu a função de Iman. Na prática, a sala de oração deveria ser reformada e ampliada. Foi instalado um autofalante na parte exterior do clube para o chamado da oração, o Adham. Enfim, comemorou-se. Parece que alguém fará a religiosidade acontecer na cidade, como o esperado pelos antropólogos que estudam imigrantes.

Entretanto, o rapaz se diz apenas formado em engenharia e conhecedor do árabe e não um líder espiritual. Em nossa conversa, suas preocupações centram-se mais na heresia e no ateísmo, mas são apenas comentários adicionais às preocupações que tem com o mundo de perigos das ruas. Uma preocupação que engloba os destinos dos filhos e das filhas de imigrantes sem ter o que ocupar-se depois da 
escola, se não estão trabalhando envolvidos nas lojas. Os imigrantes mais velhos que ocupam a sala de oração são receptivos, porque ele é, sobretudo, um filho de um imigrante local e não um Iman forasteiro a ser hospedado com honrarias.

Enzo Pace (1997) escreveu que são exatamente os autodidatas, aqueles que se defrontam com a leitura do Corão, que se afastam da exegese canônica, abrem caminhos a um islamismo radical. Seguese observando condutas e o que os imigrantes têm apontado para os destinos de sua comunidade, em diversos níveis de suas relações intercomunitárias e intracomunitárias.

Enfatiza-se que a relativa ausência da religião nas imagens amplificadas pela comunidade imigrante na cena pública não expressa uma falta de sentimento de coletividade ou uma negligência com a religiosidade. Ela apenas frustra os estereótipos que se leva a campo, de que uma religião para os imigrantes seria uma das bases que potencializaria processos de comunização. Tal premissa sempre nos ancorou, com enormes dilemas e desconfortos, ao ponto de vista dos líderes religiosos como decodificadores por excelência da experiência religiosa.

E quando isso não ocorre? Como explicar? Poderia debitar isso rapidamente na conta do sunismo e de suas bases avessas à centralidade de lideranças espirituais? Afinal, estes interlocutores eram enfáticos em afirmar que qualquer lugar onde se faça a oração deve ser puro e não necessita ser uma mesquita. Observando as experiências cotidianas dessa coletividade aponta-se a necessidade de buscar mais informações sobre onde e de que modo a religiosidade perpassa suas experiências cotidianas, para além de estereótipos que a própria literatura sobre imigração possa reforçar, como uma religião de um grupo minoritário. Considerando, portanto, as sugestões de Roberto Cardoso de Oliveira quando refere ao terreno das moralidades como um lugar de diálogo e de exercício da argumentação, o que delinea alguns dos debates sobre os cuidados com os seus e com os outros.

Nesse sentido, a ausência dos imans não significa a ausência de um campo de preocupações, vigilâncias e embates sobre moralidades, e que não se reduzem a uma observação sobre um estável "nós, os muçulmanos", mas é, sim, um ponto de observação e debate sobre a 
vida comunitária e, em especial, sobre uma comunidade moral sempre permeável e permeada por novas situações e acontecimentos.

Ao final, levanta-se mais perguntas do que visões panorâmicas sobre o islamismo no Brasil. Cabe indagar sempre: onde estamos nesse jogo de estereótipos? Muitas vezes nos limitamos a atuar como tradutores ou, de fato, desvendamos os jogos que produzem e reiteram estereótipos? Interpelados também pelas mídias sobre quem são os muçulmanos, nós somos rapidamente englobados nesse jogo manejando a competência de bons tradutores de significados. Entretanto, corremos o risco de acabar reduzidos a nos dedicar a refutar as armadilhas huntingtonianas do choque de civilizações, como previne Maria Cardeira da Silva (2008). Por vezes, demasiadamente ocupados em desarmar noções orientalistas, será que não acabamos por reforçar um papel, incômodo decerto, de reveladores do islamismo? Se nos ocuparmos em desconstruir discursos abrangentes sobre os muçulmanos no Brasil e a "islamofobia" não estaríamos indiretamente reduzindo nosso alcance interpretativo?

Uma anotação final. Não foi intuito tornar as reflexões trazidas deste trabalho de campo um laboratório das experiências religiosas muçulmanas no Brasil, nem, ao contrário, torná-la uma exceção à regra, um caso isolado e pitoresco. Deseja-se problematizar nossa aproximação e coparticipação na produção de estereótipos sobre a religiosidade muçulmana no Brasil como acadêmicos que dão visibilidade ao tema, muitas vezes atrelados a exigências discursivas que se impõem ao pesquisador. Enfim, é possível considerar a religiosidade muçulmana uma experiência sensível entre outras, que perfaz um comentário sobre condutas e participa de batalhas sobre (i)moralidades, debatendo e polemizando sobre as formas de relacionar-se em comunidade. Esse é um tema e um drama que, contextualmente, não é uma preocupação exclusiva de muçulmanos. 


\section{Notas:}

1 Este trabalho é uma versão modificada daquele apresentado na $27^{\mathrm{a}}$ Reunião Brasileira de Antropologia, em Belém do Pará, Brasil na MR02: Afro-brasileiros, islâmicos e pentecostais e a vida ordinária dos estereótipos. Quero agradecer à Clara Mafra pela oportunidade de interlocução e as críticas e comentários que incorporei, os quais são decorrentes de nosso debate.

2 A este respeito há uma extensa produção que desvenda a expansão de mesquitas como uma chave de leitura para a compreensão das comunidades muçulmanas no Brasil. Uma produção mais recente analisa do ponto de vista antropológico os diversos itinerários e configurações da comunidade muçulmana. Ver Pinto (1997) e Ferreira (2010), Machado de Oliveira e Jardim (2007), entre outros.

3 Além disso, estruturalmente, podemos esboçar um quadro de disputas simbólicas, como situaria Pierre Bourdieu, relativas a uma "fração dominada da classe dominante" o que faz com que as disputas simbólicas sejam bem explícitas no que tange à disputa de reconhecimento simbólico na localidade. Ou seja, o status econômico alcançado não tem correspondência direta com a ocupação dos lugares de decisão na localidade.

4 Sanaud - grupo de jovens fomentado pela a OLP de Brasília; contava com uma maioria de filhos de palestinos no Chuí.

5 Sanaud significa voltaremos em árabe.

6 A Rede Dubai está sediada na cidade de Dubai. O nome faz referência ao mesmo tempo a uma rede de informações de alcance internacional - e não só local e circunscrito ao mundo árabe - e ao canal de televisão que mantém uma programação diversificada com novelas, orações, propagandas e noticiários.

7 As atenções dos jornalistas se detinham inicialmente na autoria e interpretações de imigrantes árabes a partir dos boatos sobre os fogos de artifício lançados no Chuí durante a transmissão dos ataques às torres gêmeas.

8 O nome é usado de forma pejorativa e amplamente conhecido pelos árabes da localidade, pois remete a um campo de refugiados, uma favela como dizem, e é utilizado como metáfora para evidenciar o comércio "dos pequenos comerciantes" e lembra, de forma pejorativa, entre os imigrantes, o mercado de coisas baratas, evocando precariedade e pobreza.

9 Ver o diálogo entre universos de pesquisa que fizemos em Magalhães e Jardim (2009) e das considerações sobre a mídia em nossa reflexão etnográfica a partir das propostas de Magalhães (2004).

10 Said (1990) denuncia a construção do "exótico" e, também nesse caso, o ato de orientalizar os costumes do outro. Seria uma retórica de apreensão e de poder que se potencializa em situações concretas e que lançam mão de um repertório intensamente conhecido e reiterado por inúmeras imagens midiáticas, da literatura e da arte. Enfim, do próprio campo científico ao qual o autor nomeia como "orientalismo". Maria Cardeira da Silva (2008) recupera essa crítica e se refere às "armadilhas huntingtonianas" que enfatizam a diferença como choque de civilizações e acabam por essencializar a diferença. 


\section{Referências}

FERREIRA, Francirosy Campos B. (Org.). Olhares Femininos Sobre o Islã. 1 ed. São Paulo: Hucitec, 2010. v. 1, p. 176-197.

GEERTZ, C. A Interpretação das Culturas. Petrópolis: Vozes, 1989.

JARDIM, Denise F. Estratégias de Imigração em tempos da globalização: os palestinos e suas viagens internacionais. In: JARDIM, Denise F. (Org). Cartografias da Imigração: interculturalidade e políticas públicas. Porto Alegre: Editora da Universidade/UFRGS, 2007.

MACHADO DE OLIVEIRA, M. A.; JARDIM, Denise F. (Org.). Os Árabes e suas Américas. Corumbá: Ed. UFMS, 2007.

MAGALHÃES, Nara M. E. Televisão, uma vilã na sociedade contemporânea - um estudo sobre modos de ver (a) TV de pessoas pertencentes a camadas médias. Tese de Doutorado. PPGAS da Universidade Federal de Santa Catarina, 2004.

MAGALHÃES, N. M.; JARDIM, D. F. Televisão e imigração palestina: perigos e invisibilidades no trabalho de campo. Iberoamerica global, Jerusalem, v. 2, n. 1, p. 71-93, 2009.

OLIVEIRA, Roberto Cardoso. Antropologia e Moralidade. [2011]. In: RBCS. n. 24. Disponível em: <www.anpocs.br> [on-line]. Acesso em: 7 nov. 2011.

PACE, Enzo. Religião e Globalização. In: ORO, A.; STEIL, C. (Org.). Globalização e Religião. Petrópolis: Vozes, 1997.

PINTO, Paulo. A Casa do Islam: igualitarismo e holismo nas sociedades muçulmanas. Antropolítica (UFF), Niterói, v. 3, p. 91-119, 1997.

SAID, Edward. Orientalismo: o Oriente como invenção do Ocidente. São Paulo: Cia das Letras, 1990.

SILVA, Maria Cardeira DA. As mulheres, os outros e as mulheres dos outros: feminismo, academia e Islão. Cadernos Pagu, n. 30, p. 137-159, jan.jun. 2008.

VÁZQUEZ, Joan Lacomba. El Islam Inmigrado: transformaciones y adaptaciones de las prácticas cultuales y religiosas. Ministerio de Educación, Cultura y Deporte, SEC, España, 2000.

VELHO, Otávio. Globalização: antropologia e religião. In: ORO, A.; STEIL, C. (Org.). Globalização e Religião. Petrópolis: Vozes, 1997.

Recebido em 06/01/2012

Aceito em 30/01/2012 